\title{
Cloning of the Mammalian Type II lodothyronine Deiodinase A Selenoprotein Differentially Expressed and Regulated in Human and Rat Brain and Other Tissues
}

Walburga Croteau, Jennifer C. Davey, Valerie Anne Galton, and Donald L. St. Germain

Departments of Medicine and Physiology, Dartmouth Medical School, Lebanon, New Hampshire 03756

\begin{abstract}
The deiodination of thyroid hormones in extrathyroidal tissues plays an important role in modulating thyroid hormone action. The type II deiodinase (DII) converts thyroxine to the active hormone $3,5,3^{\prime}$-triiodothyronine, and in the rat is expressed in the brain, pituitary gland, and brown adipose tissue (BAT). Complementary DNAs (cDNAs) for the types I and III deiodinases (DI and DIII, respectively) have been isolated and shown to code for selenoproteins. However, information concerning the structure of the mammalian DII remains limited, and the pattern of its expression in human tissues is undefined. We report herein the identification and characterization of rat and human DII cDNAs. Both code for selenoproteins and exhibit limited regions of homology with the DI and DIII. In the rat pituitary and BAT, DII mRNA levels are altered more than 10 -fold by changes in the thyroid hormone status of the animal. Northern analysis of RNA derived from human tissues reveals expression of DII transcripts in heart, skeletal muscle, placenta, fetal brain, and several regions of the adult brain. These studies demonstrate that: $(a)$ the rat and human DII are selenoproteins, (b) DII expression in the rat is regulated, at least in part, at the pretranslational level in some tissues, and (c) DII is likely to be of considerable physiologic importance in thyroid hormone economy in the human fetus and adult. (J. Clin. Invest. 1996. 98:405-417.) Key words: thyroid • selenium • metabolism • development • fetus
\end{abstract}

\section{Introduction}

In some mammalian tissues, such as the developing brain, the anterior pituitary gland, and brown adipose tissue (BAT) ${ }^{1}$, where thyroid hormone appears to have particularly important regulatory effects, a relatively high proportion of the receptor-

Address correspondence to Donald L. St. Germain, Dartmouth Medical School, One Medical Center Drive, Lebanon, NH 03756. Phone: 603-650-7910; FAX: 603-650-6130; E-mail: stgermain@dartmouth.edu

Received for publication 13 February 1996 and accepted in revised form 9 April 1996.

1. Abbreviations used in this paper: 5 -D, 5-deiodinase; $5^{\prime}$-D, $5^{\prime}$-deiodinase; BAT, brown adipose tissue; DI, type I deiodinase; DII, type II deiodinase; DIII, type III deiodinase; PTU, 6- $n$-propyl-2-thiouracil; $\mathrm{rT}_{3}, 3,3^{\prime}, 5^{\prime}$-triiodothyronine; SECIS, selenocysteine insertion sequence; $\mathrm{T}_{3}, 3,5,3^{\prime}$-triiodothyronine.

J. Clin. Invest.

(C) The American Society for Clinical Investigation, Inc.

0021-9738/96/07/0405/13 \$2.00

Volume 98, Number 2, July 1996, 405-417 bound 3,5,3'-triiodothyronine $\left(\mathrm{T}_{3}\right)$ is produced within the tissue itself, rather than being derived from plasma (1-4). The expression in these tissues of the type II iodothyronine deiodinase (DII), which catalyzes deiodination of thyroxine $\left(\mathrm{T}_{4}\right)$ exclusively on the outer ring ( $5^{\prime}$-position) to yield $\mathrm{T}_{3}$, strongly suggests that this enzyme is responsible for this "local" production of $\mathrm{T}_{3}$ and is thus important in influencing thyroid hormone action in these tissues (5). In addition, DII activity is markedly elevated in the hypothyroid state and appears to be responsible for catalyzing the production of a large proportion of the circulating $\mathrm{T}_{3}$ under such conditions (6). For example, in neonatal rats, circulating $\mathrm{T}_{3}$ levels are not reduced when the type $\mathrm{I}$ deiodinase (DI) is inhibited by 6 - $n$-propyl-2-thiouracil (PTU), a specific inhibitor of this enzyme (2). Thus, DII is of critical importance for both the local generation of $\mathrm{T}_{3}$ in selective tissues and systemic thyroid hormone homeostasis.

Complementary DNAs for the DI and type III deiodinase (DIII) have recently been isolated and demonstrated to contain in-frame TGA codons that code for selenocysteine (7-10). The catalytic properties and tissue patterns of expression of these selenoproteins differ from those of the DII. Thus, DI appears to play an important role in converting $T_{4}$ to $T_{3}$ within the thyroid gland itself $(11,12)$, and, unlike DII, is expressed in the liver and kidney and is capable of inner ring (3- or 5-position) deiodination of sulfated thyroid hormone conjugates (13). DIII functions as an inner ring deiodinase to convert $T_{4}$ and $\mathrm{T}_{3}$ to inactive metabolites $\left(3,3^{\prime}, 5^{\prime}\right.$-triiodothyronine $\left[\mathrm{rT}_{3}\right]$ and 3,3'-diiodothyronine, respectively). Its expression in placenta and several fetal tissues during early development suggests that it plays a role in preventing premature exposure of developing tissues to adult levels of thyroid hormones (14). The DII also is present in several fetal and neonatal tissues (15) and is essential for providing the brain with appropriate levels of $\mathrm{T}_{3}$ during the critical period of development (16).

Isolating cDNAs for DII has been problematic. Our attempts at screening appropriate cDNA libraries under reduced stringency conditions using DI and DIII cDNAs as probes has proved unsuccessful (Croteau, W., M. Schneider, and D.L. St. Germain, unpublished data). Furthermore, unlike the DI and DIII, the DII is poorly expressed in Xenopus laevis oocytes after the injection of poly $(\mathrm{A})^{+}$RNA from DII-containing tissues (17), thus rendering this expression system untenable as a tool for screening cDNA libraries. However, using a PCR-based strategy, we have recently cloned a cDNA (designated RC5'DII) for the DII of the amphibian species Rana catesbeiana (Davey et al., reference 18). In the present studies, we used this amphibian DII cDNA to identify homologous rat and human cDNAs. We have demonstrated that these cDNAs code for selenoproteins with DII activity. The predominant mRNA species for these mammalian enzymes are $6-8 \mathrm{~kb}$ in size and are highly expressed in a number of tissues including the fetal and adult brain of rats and humans, and in human heart, placenta, and skeletal muscle. 


\section{Methods}

RNA preparation and Northern analysis. RNA was prepared as previously described (19) from BAT of male Sprague-Dawley rats (Charles River Laboratory, Wilmington, MA) (150-175 g) exposed to cold $\left(4^{\circ} \mathrm{C}\right)$ for $24 \mathrm{~h}$. Poly(A) ${ }^{+}$RNA was isolated by one or two cycles of chromatography over oligo(dT)-cellulose (Collaborative Biomedical Products, Bedford, MA). RNA from other rat tissues used for Northern analysis was prepared by the same methods. RNA blots of human tissues were purchased from Clontech (Palo Alto, CA) and contained $\sim 2 \mu \mathrm{g}$ of poly $(\mathrm{A})^{+}$RNA per lane according to the supplier's specifications. Hybridization and washing of Northern blots were performed as previously described for rat tissues (20), or according to the supplier's instructions for blots of human tissues, except that final washes were performed at 42 or $60^{\circ} \mathrm{C}$ instead of $50^{\circ} \mathrm{C}$. In some experiments, rats were rendered hypothyroid by the inclusion of $0.05 \%$ methimazole in their drinking water for 25-30 d, or hyperthyroid by a single daily subcutaneous injection of $50 \mu \mathrm{g} \mathrm{T} / 100 \mathrm{~g}$ body wt for $4 \mathrm{~d}$ before killing. After hybridization with the specific DII probes identified in these studies, blots were stripped and reprobed with a mouse, rat, or human $\beta$-actin probe. Hybridization signals were quantified by densitometric measurements of scanned computer images of the autoradiographs using the IPLab Gel program (Signal Analytics Corp., Vienna, VA) on a Macintosh computer. In all cases, signals obtained using the DII probes were normalized using the signals generated with a $\beta$-actin probe.

cDNA probe preparation. cDNA probes for Northern analysis and library screening were prepared by PCR using the appropriate cDNAs as templates and gene-specific sense and antisense primers that flanked the regions of interest. After amplification, the PCR reaction products were separated on a low melt agarose gel stained with ethidium bromide, and the appropriate band was then excised and purified using a QIAquick Gel Extraction Kit (Qiagen Inc., Chatsworth, CA). The PCR product was then labeled with ${ }^{32} \mathrm{P}$ using the Oligolabeling Kit from Pharmacia LKB Biotechnology Inc. (Piscataway, NJ).

cDNA library construction and screening. Poly $(\mathrm{A})^{+}$RNA from BAT of cold-exposed rats was used to prepare a cDNA library in the Uni-Zap XR Vector according to the kit manufacturer's instructions (Stratagene Inc., La Jolla, CA). First-strand cDNA synthesis was primed by the oligo-(dT) linker provided in the kit. Screening of the library was performed using plaque hybridization under low stringency conditions according to the methods of Lees et al. (21). The first 305 nucleotides of the coding region of the RC5'DII were used as a probe. (This region of the deiodinase proteins is the least conserved among the three enzyme subtypes. Thus, the use of the $5^{\prime}$ portion of the coding region made it less likely that DI and DIII cDNAs would be identified during the screening process.) Positive plaques were detected by autoradiography and purified by additional rounds of screening using the hybridization conditions described above. cDNA inserts were sequenced on both strands using vector and genespecific primers and an automated sequencing system with fluorescent dye terminators (Applied Biosystems Inc., Foster City, CA).

Expression studies in X. laevis oocytes and COS-7 cells. Stage 5-6 X. laevis oocytes were isolated and each microinjected as previously described (19) with $50 \mathrm{ng}$ of in vitro-synthesized, capped RNA transcripts prepared using the MEGAscript kit (Ambion Inc., Austin, TX). After injection, oocytes were incubated for 3-4 d in Barth's medium (for determination of 5-deiodinase [5D] activity) or L-15 medium (for determination of $5^{\prime}$-deiodinase [ $\left.5^{\prime} \mathrm{D}\right]$ activity), and then harvested. Membrane fractions were prepared as described previously (22).

For expression in COS-7 cells, rat and human DII cDNAs and the G21 rat DI cDNA (kindly provided by Drs. M. Berry and P.R. Larsen, Brigham and Women's Hospital, Boston, MA) were subcloned into the pcDNA3 mammalian expression vector (Invitrogen Corp., San Diego, CA). Cells were grown and maintained in DME supplemented with $10 \%$ iron-supplemented calf serum (Sigma Chemical Co., St. Louis, MO). Cells $\left(10^{7}\right.$ in Hepes-buffered saline) were transfected with $22 \mu \mathrm{g}$ of plasmid DNA using an Electroporator (Bio-Rad Laboratories, Hercules, CA), and then maintained in culture medium for $48 \mathrm{~h}$ before harvesting. After aspiration of the medium, cell monolayers were washed twice with phosphate-buffered saline, and then scraped from the dish, pelleted, and sonicated in $0.25 \mathrm{M}$ sucrose, $0.02 \mathrm{M}$ Tris/HCl, $\mathrm{pH}$ 7.4.

$5 ' \mathrm{D}$ and $5 \mathrm{D}$ activity were determined in oocyte membrane preparations or COS-7 cell sonicates according to published methods (17, $22)$. For the $5^{\prime} \mathrm{D}$ assay, the reaction buffer contained $1 \mathrm{mM}$ EDTA. In kinetic studies, $5^{\prime} \mathrm{D}$ activity was determined using either $0.5-16 \mathrm{nM}$ $\left[{ }^{125} \mathrm{I}\right] \mathrm{rT}_{3}$ or $0.5-12 \mathrm{nM}\left[{ }^{125} \mathrm{I}\right] \mathrm{T}_{4}$ with $20 \mathrm{mM}$ dithiothreitol as cofactor. Kinetic constants were determined from double reciprocal plots. ${ }^{125} \mathrm{I}-$ labeled iodothyronines used as substrates were obtained from Du Pont de Nemours (Boston, MA) and purified by chromatography using Sephadex LH-20 (Sigma Chemical Co.) before use. In other experiments, the deiodinase activities in oocyte membrane preparations or COS-7 cell sonicates were determined in the absence or presence of PTU $(10-900 \mu \mathrm{M})$ or aurothioglucose $(0.01-10 \mu \mathrm{M})$. 5'D activity was measured using $1.5 \mathrm{nM}\left[{ }^{125} \mathrm{I}\right] \mathrm{rT}_{3}$ as substrate and $20 \mathrm{mM}$ dithiothreitol as cofactor.

Protein concentrations were determined by the method of Bradford (23) with reagents obtained from Bio-Rad Laboratories.

Reverse transcriptase-PCR assay. Coupled reverse transcription and PCR amplification was used to determine the presence of DII transcripts in selected adult rat tissues including BAT from a hypothyroid animal, and liver and white fat from a normal animal. Reactions used the Access RT-PCR System (Promega Corp., Madison, WI) with poly(A) ${ }^{+}$RNA $(1 \mu \mathrm{g})$ as a template. Reaction conditions were as specified by the manufacturer except that 30 or 35 cycles were used in the PCR. Specific oligonucleotide primers derived from the coding region of the rat DII sequence (sense: ACTCGGTCATTCTGCTCAAG; antisense: TTCAAAGGCTACCCCATAAG) were used to prime first-strand cDNA synthesis, and then the amplification of a predicted 590-bp PCR product. Reaction mixtures lacking reverse transcriptase or an RNA template were used as controls. Products were then separated on a $1.0 \%$ agarose gel, transferred to a nylon membrane (Magna Charge Micron Separations, Inc., Westboro, MA), and hybridized with a radiolabeled nested oligonucleotide rat DII probe (AATGCCACCTTCTTGACTTT). After washing, the blot was exposed to $\mathrm{x}$-ray film for $12 \mathrm{~h}$. The signals were quantified using a phosphoimager (Molecular Dynamics, Inc., Sunnyvale, CA).

Preparation of chimeric DII/DIII cDNAs. Chimeric cDNAs were constructed by splicing part or all of the $3^{\prime}$-untranslated region of the full length rat DIII cDNA (rNS43-1), which contains an active selenocysteine insertion sequence (SECIS element), to the $3^{\prime}$ end of the coding regions of the rat BAT 1-1 or human Z44085 DII cDNAs (Fig. 1). The 3'-untranslated portion of the rNS43-1 was amplified by PCR using sense primers that included, at their $5^{\prime}$ ends, 19 or $20 \mathrm{nu}-$ cleotides of the rat or human DII cDNA, and the antisense pBlueScript M13 forward primer. Conditions for these PCR reactions varied, but generally included 28 to 35 cycles of amplification involving $94^{\circ} \mathrm{C}$ for $1 \mathrm{~min}, 53$ or $57^{\circ} \mathrm{C}$ for $45 \mathrm{sec}$, and $72^{\circ} \mathrm{C}$ for $1.5 \mathrm{~min}$, and a final 10 -min extension period. PCR reaction products were purified as described above for CDNA probe preparation.

For construction of the rBAT 1-1 coding region/rat DIII SECIS chimera cDNA (Fig. $1 A$ ), the rNS43-1 3'-untranslated region was amplified with primers 1 and 2, and the PCR product was then digested with $\mathrm{XbaI}$ and ApaI. This was then subcloned into the rat BAT 1-1 DII pcDNA3 construct that had been truncated in the 5 '-untranslated region at a BamHI site and, after relegation, digested with XbaI and ApaI to remove the $3^{\prime}$-untranslated region of the rat DII clone. This construct retained the entire coding region and stop codon of the rat DII clone, although the stop codon was changed from TAG to TAA. The 5'-truncated Bat 1-1 clone was used for this construct because of the possibility that a shorter $5^{\prime}$-untranslated region would allow higher levels of expression in $X$. laevis oocytes.

For constructing the hZ44085 coding region/rat DIII SECIS chimera cDNA, convenient restriction sites near the $3^{\prime}$ end of the human 
A
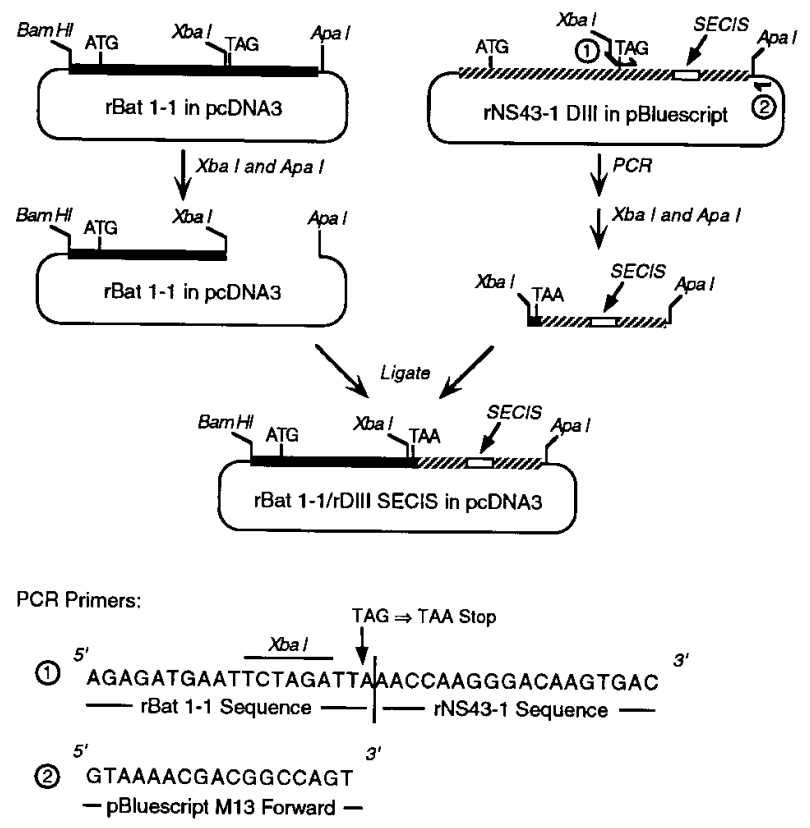

\section{B}

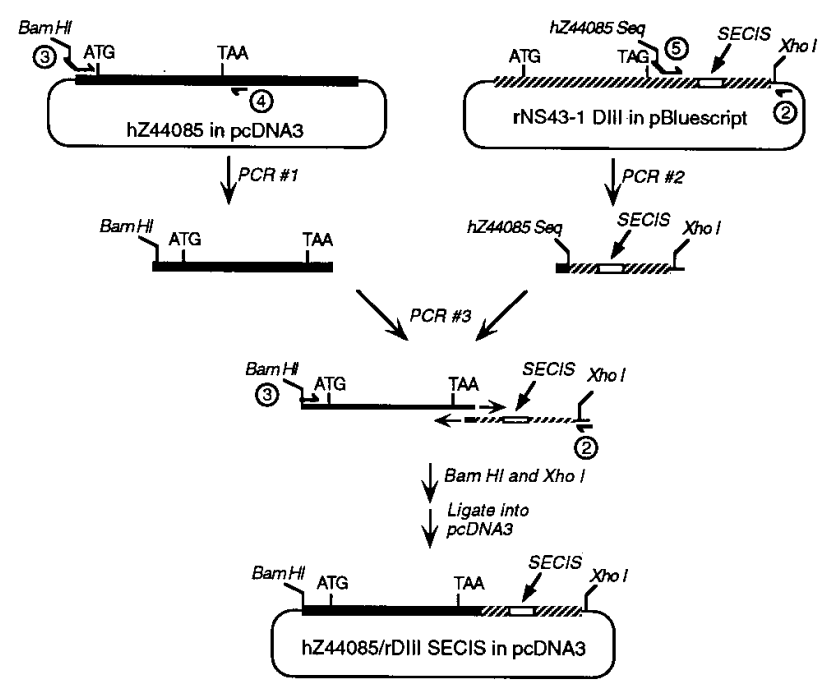

PCR Primers:

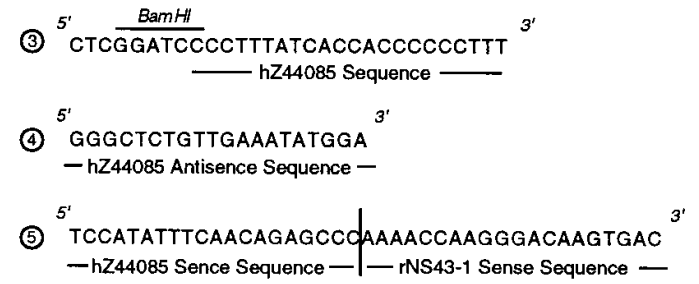

Figure 1. Schematic diagram outlining the strategy for construction of $(A)$ the rBAT 1-1/rDIII SECIS and $(B)$ the hZ44085/rDIII SECIS chimeric cDNAs. Sequences of the oligonucleotides used as PCR primers are shown in the lower part of each figure. Primer 2 was used in both schemes. See text for detailed description of methodology.

DII coding region were not available, hence an overlap extension PCR method (24) was used (Fig. $1 B$ ). The coding region of the human Z44085 DII cDNA was amplified using sense primer 3, whose sequence was derived from the $5^{\prime}$-untranslated region of the clone (with a BamHI restriction site included near the $5^{\prime}$ end of the oligonucleotide), and an antisense primer 4 , located in the $3^{\prime}$-untranslated region at 70 nucleotides $3^{\prime}$ to the TAA stop codon. The rNS43-1 $3^{\prime}$-untranslated region for this construct was amplified with primer 5, that contains hZ44085 sequences at its $5^{\prime}$ end, and primer 2. After gel purification, these PCR products were spliced together in an overlap extension PCR reaction to yield the full length chimeric hZ44085/rat DIII SECIS cDNA, which was then digested with BamHI and XhoI and cloned into the pcDNA3 vector. Conditions of these PCR reactions were the same as those noted above for amplification of the 3 -untranslated portion of the rNS43-1. Critical regions of the chimeric cDNAs were sequenced to insure the accuracy of the construction methods.

Other methods. Kinetic constants were determined by linear regression analysis of double reciprocal plots. Results are reported as the mean \pm SEM. Statistical analysis used Student's $t$ test with the Bonferroni correction applied for multiple comparisons (25). The evolutionary tree diagram was produced with the GeneWorks program (IntelliGenetics, Mountain View, CA) using the unweighted pair group method with arithmetic mean.

\section{Results}

Previous studies employing actinomycin D have provided indirect evidence that the adrenergically mediated cold-induced stimulation of DII activity in rat BAT results from transcriptional activation and an increase in DII mRNA levels $(26,27)$. Thus, as an initial step in isolating a cDNA for the rat DII, we constructed a cDNA library from poly $(\mathrm{A})^{+}$RNA derived from the BAT of rats exposed to $4^{\circ} \mathrm{C}$ for $24 \mathrm{~h}$. Screening the library by plaque filter hybridization at reduced stringency with a 305-bp fragment from the coding region of the RC5'DII resulted in the isolation of 13 clones containing two different cDNA inserts. The clone containing the largest cDNA $(1.9 \mathrm{~kb}$, designated rBAT 1-1) was sequenced on both strands (Fig. 2 $A)$. rBAT 1-1 contains an open reading frame of 798 nucleotides that includes two in-frame TGA codons. The first (cDNA nucleotide 951, codon 130) is located in a region that exhibits high homology with the regions in RC5'DII, DI, and DIII cDNAs that contain a TGA triplet that codes for selenocysteine. The second TGA triplet (codon 262) is located four codons upstream from an unambiguous TAG stop codon and is not present in any other deiodinase cDNA previously isolated. The other, smaller cDNA isolated from the BAT library was also sequenced and found to be identical to portions of the BAT 1-1 clone, including the presence of both TGA codons, thus confirming their presence in the rat DII homolog. The 798-nucleotide open reading frame of the rBAT 1-1 cDNA is predicted to code for a protein of 266 amino acids of $29.8 \mathrm{kD}$. If translation stopped at the second TGA codon, rather than the downstream TAG, a slightly smaller protein would result.

A search of GenBank revealed a DNA sequence (acces- 
CCCAAACAACCCTTGCGCTTACAGCACAGTTAAGAAATTGGCAGTGTAAGAAGCCAGACT GCGTTTAAAGGAACATGAAAAGCTAAAAGAAATTTTTACCATCTCTGCAGTCTCATAGGT GCCTGGAAATGAAAGTAGAACTTCCTGTCTTTAACGGACTCTGACAGGGGTAAACTGGAT TAGGGACTGGCACGCCAGGGTGTTGTTGTTGTTGTTGTTGTTGTTTNGTTGTTGTTGTTG CTGGGAGTGGTGGTGTTTTGTTTTTTTTTTTTAACCATCTTAAATCCTGGAAAAAAAATG CATCTCGGAATTGAATGAATTGATGGGTCCACTCCAACTGCTGGGCTGCAGAGACTGAAC TTGGTCTTTCCATTTCTGCTTCTTTCAAAGAAGAGACAAGTTGGGATCCCTTCTAATTTA GCTTTTCTCCCTCTCCCTCACCCCCCACCCCCACTCCCAACCTTCCCCTTGGTCCCCCAC TTCTCTACCACCACCTTCCTTTGCAAAAAGGGGGTGACCGGGGAAGCAGAGTGCACAGGA GACTGACTGAGGAGGTAAAGAAGATGGGACTCCTCAGCGTAGACTTGCTGATCACTCTTC

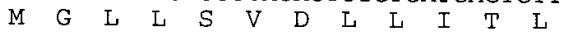

AGATTCTGCCAGTCTTTTTCTCCAACTGCCTCTTCCTGGCGCTCTATGACTCGGTCATTC 660

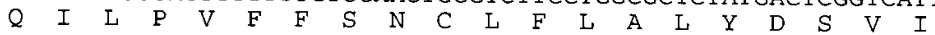

TGCTCAAGCACGTGGCGCTGCTTCTCAGCCGCTCCAAGTCCACTCGCGGAGAGTGGAGGC 720 $\begin{array}{lllllllllllllllllllllll}L & L & K & H & V & A & L & L & L & S & R & S & K & S & T & R & G & E & W & R\end{array}$

GCATGCTGACCTCAGAAGGACTACGCTGTGTCTGGAACAGCTTTCTCCTAGACGCCTACA $\begin{array}{llllllllllllllllllll}R & M & L & T & S & E & G & L & R & C & V & W & N & S & F & L & L & D & A & Y\end{array}$

AACAGGTTAAATTGGGTGAAGATGCTCCCAATTCCAGTGTGGTGCACGTGTCCAATCCTG 840 $\begin{array}{llllllllllllllllllll}K & Q & V & K & L & G & E & D & A & P & N & S & S & V & V & H & V & S & N & P\end{array}$

AAGCAGGTAACAATTGTGCCTCAGAGAAGACGGCGGATGGGGCTGAATGCCACCTTCTTG 900 $\begin{array}{llllllllllllllllllll}E & A & G & N & N & C & A & S & E & K & T & A & D & G & A & E & C & H & L & L\end{array}$

ACTTTGCCAGTGCAGAGCGCCCACTGGTGGTCAACTTTGGTTCAGCGACCTGACCACCTT 960

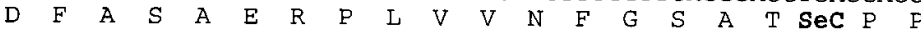

TTACTAGGCAACTGCCAGCCTTCCGCCAGTTGGTGGAAGAGTTCTCCTCGGTGGCTGACT 1020 $\begin{array}{llllllllllllllllllll}F & T & R & Q & L & P & A & F & R & Q & L & V & E & E & F & S & S & V & A & D\end{array}$

TCCTGTTGGTATACATTGATGAGGCTCACCCTPCAGATGGCTGGGCAGTGCCTGGGGACT 1080 $\begin{array}{lllllllllllllllllllll}F & L & L & V & Y & I & D & E & A & H & P & S & D & G & W & A & V & P & G & D\end{array}$

CCTCTATGTCTTTTGAGGTTAAGAAGCACCGGAACCAAGAGGACCGATGTGCTGCAGCCC 1140 $\begin{array}{llllllllllllllllllllllll}S & S & M & S & F & E & V & K & K & H & R & N & Q & E & D & R & C & A & A & A\end{array}$

ACCAGCTCCTGGAGCGTTTCTCCTTGCCGCCCCAGTGTCAAGTTGTGGCTGACCGCATGG 1200 $\begin{array}{lllllllllllllllllllll}H & Q & L & L & E & R & F & S & L & P & P & Q & C & Q & V & V & A & D & R & M\end{array}$

ACAATAATGCCAACGTAGCTTATGGGGTAGCCTTTGAACGTGTGTGCATCGTGCAGAGAC 1260 $\begin{array}{llllllllllllllllllll}D & N & N & A & N & V & A & Y & G & V & A & F & E & R & V & C & I & V & Q & R\end{array}$

GGAAAATTGCTTACTTAGGAGGGAAGGGCCCCTTCAGCTATAACCTGCAAGAAGTCCGAA 1320 $\begin{array}{lllllllllllllllllllllllllllll}R & K & I & A & Y & L & G & G & K & G & P & F & S & Y & N & L & Q & E & V & R\end{array}$

GTTGGCTGGAGAAGAATTCAGCAAGAgATGAATTCTAGATTAGCTGGATAAAAGTGTGA 1380 $\begin{array}{lllllllllllllll}S & W & L & E & K & N & F & S & K & R & \star & I & L & D & S t O p\end{array}$

TTGTAATAGAGTTTATTATTTTAAAAGAATGTGTAAAAGTTGAGAACTGAACTGAATCTA 1440 TTATTTCAACGGAATCCCATCGCCTCACTGAAAGACGGGTCATACCTGTCAGAAGATCTT 150 GAACCTCTTTAACATCTCAGTACTTCCTTTAGTACACAAACGGCATCTGGCTAAACAGCA 1560 GCCCTGTTACCTACCTTCAGAGCTAACTGGTCCAAAATGGAGGGCCAGAAACCCCGTTGC 1620 AGCCTTGTTCATTCTCGCTTGTGAAAGAAGTGATGCTGCCCTATGTGTGCTCTGGGACTA 1680 GAGGACAAAAGTTCCCAGAAAACCTATTGTTAAGGGAGCTACTACCTATGATCTGATTAA 1740 GTGTATTGTCTCAGTCAGCTTTAGTCACCAGAAGTAAACCCAACTGGAAAGTCCCCCCAA 1800 ATACATACTTATAATGTGAAAAAAAAAAAAAAAAAAAAAAAAAAAAAAAAAAAAAAAAAA 1860 AAAAAAAAAAAAAAAAAAA $\quad 1879$

B

Rana MGILSVDLLI TLQILPgFFS NCLFLALYDS VvLVKHVILq LnRSKSShGq 50

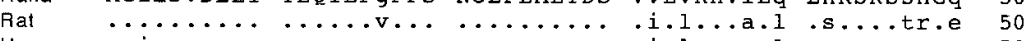

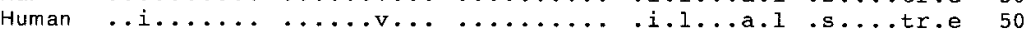

Rana WRRMLTEGL RCVWnSFLLD AYKQVKLGgD APNSnViHVT dknsssgkpg 100

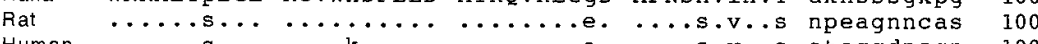

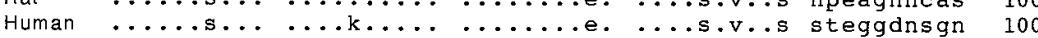

Rana tp------ CHLLDFASS ERPLVVNFGS ATXPPFisQL PAFskmVEEF 141

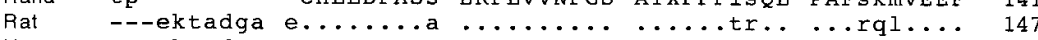

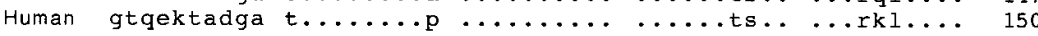

Rana SaVADFLLVy IDEAHPSDGW AaPGis--Sy EVKKHrNQED RCAAAnkLLE 189

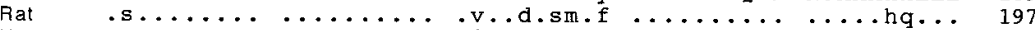

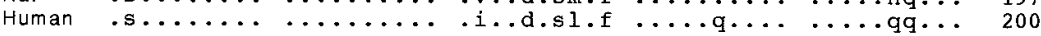

Rana GySLPPQCqV VADCMDNNTN AAYGVSFERV CIVQRqKIVY LGGKGPFfYN 239

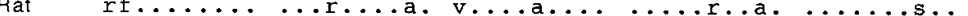

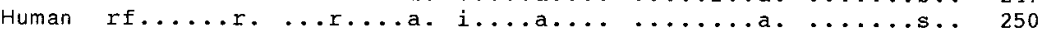

Rana LQEVRqWLEl tfgkkaesgq tgtek

Rat $\ldots$........ n.s.rxild

Human $\ldots$......k n.s.rxkktr lag

\section{0} 0 20 40 . , . 
A

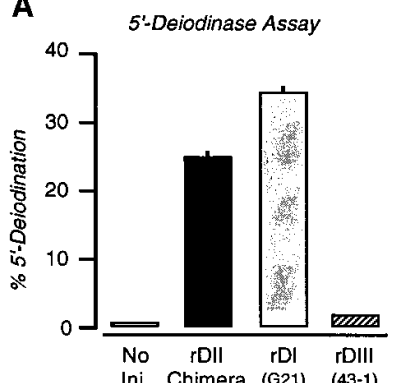

B

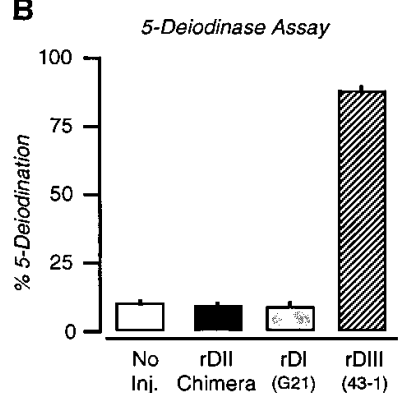

Figure 3. Expression of rat deiodinase cDNAs in X. laevis oocytes. Individual oocytes were injected with $50 \mathrm{ng}$ of in vitro-synthesized RNA transcripts prepared using T3 or T7 RNA polymerase and, as template, either the rat Bat 1-1 DII/rDIII SECIS chimera cDNA, the rat G21 DI cDNA, or the rat NS43-1 DIII cDNA. (A) 5'-deiodinase or $(B)$ 5-deiodinase activity was measured in oocyte membrane preparations. Because of high levels of activity, the G21 and NS43-1 membrane preparations were diluted 20 -fold before the 5 '-deiodinase or 5 -deiodinase assays, respectively. For each group of oocytes, both assays were conducted on aliquots of the same membrane preparations using substrate concentrations of $\sim 1.5 \mathrm{nM} \mathrm{rT}_{3}$ (5'-deiodinase assay) or $1.0 \mathrm{nM} \mathrm{T}_{3}$ (5-deiodinase assay).

sion Z44085) that is highly homologous ( $89 \%$ nucleotide identity) to a portion of the $5^{\prime}$-untranslated region and the beginning of the coding region of the rBAT 1-1 cDNA. The 320 nucleotides of the hZ44085 sequence were derived from the $5^{\prime}$ end of an expressed sequence tag isolated from a cDNA library prepared from the brain tissue of a 3-mo-old human infant. The high homology suggests that the Z44085 cDNA represents the human DII homolog. The hZ44085 cDNA was kindly provided by Genethon (Evry, France), and we sequenced it in its entirety. This cDNA is $\sim 1.9 \mathrm{~kb}$ and contains an open reading frame of 819 nucleotides that codes for a protein of $30.0 \mathrm{kD}$ (Fig. $2 \mathrm{~B}$ ) that is highly homologous to those coded by the rBAT $1-1$ and RC5'DII cDNAs (87 and 73\% amino acid residue identity, respectively). Overall, $72 \%$ of the amino acid residues have been conserved among these three proteins. The hZ44085 cDNA contains two in-frame TGA

A
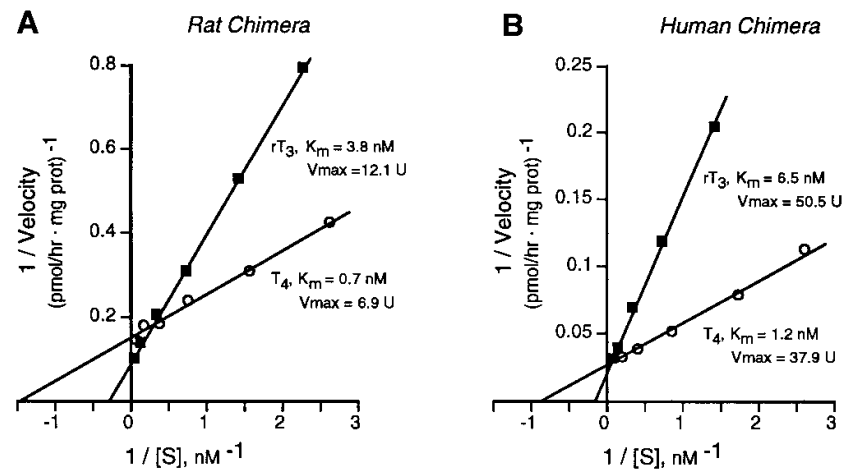

Figure 4. Kinetic analysis using $\mathrm{T}_{4}$ or $\mathrm{rT}_{3}$ as substrates of the protein products of the $(A)$ rat Bat 1-1 DII/rDIII SECIS chimera and $(B)$ human Z44085 DII/rDIII SECIS chimera as expressed in COS-7 cells. $\mathrm{V}_{\max }$ values are expressed in units of activity where $1 \mathrm{U}=1 \mathrm{pmol} / \mathrm{hr}$ per mg protein.

codons in locations analogous to those found in rBAT 1-1. As is the case for the DI and DIII proteins, the amino-terminal portions of these three proteins contain a region of 42 amino acid residues that is highly hydrophobic and may represent a membrane-spanning domain (28). The complete sequences of the rBAT 1-1 and hZ44085 cDNAs have been submitted to GenBank/EMBL/DDBJ and have been assigned accession numbers U53505 and U53506, respectively.

Attempts to demonstrate functional deiodinase activity of the rBAT 1-1 and hZ44085 proteins by either $(a)$ the injection of in vitro-synthesized RNA transcripts into $X$. laevis oocytes, or (b) transfection of the corresponding cDNAs into COS-7 cells were unsuccessful. Truncating the rBAT 1-1 cDNA of 405 nucleotides of the $5^{\prime}$-untranslated region at a BamHI site did not result in a cDNA that codes for a functional deiodinase. Examination of the 3'-untranslated region in both cDNAs suggested that they lack a classic stem-loop SECIS element that is necessary for the read through and translation of the TGA codon(s) into selenocysteine. Lacking such elements, one would predict that attempts at expression of these cDNAs would result in the formation of truncated, inactive proteins, as
A

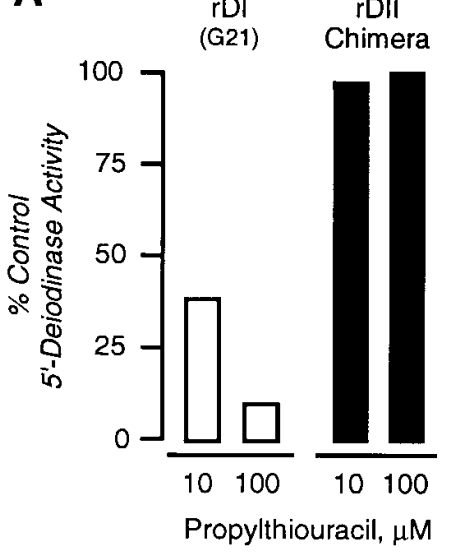

B

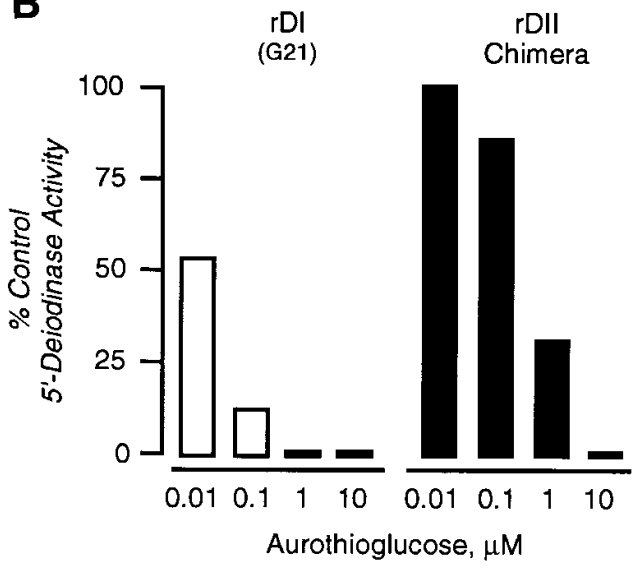

Figure 5. Sensitivity of the G21 rDI and the rBAT 1-1 DII/rDIII SECIS chimera deiodinases to the inhibitory effects of $(A)$ PTU as determined in oocyte membrane preparations and $(B)$ aurothioglucose as defined in COS-7 cell homogenates. Oocytes previously injected with RNA synthesized in vitro using the G21 rDI or rBAT 1-1 DII/rDIII SECIS chimera cDNAs as templates were harvested, membranes prepared, and then assayed for $5^{\prime}$-D activity in the presence of PTV. Control incubations were performed in aliquots of the same membrane preparations in the absence of inhibitors. For studies examining the effects of aurothioglucose, COS-7 cells were transfected with either the G21 or rBAT 1-1 DII/rDIII SECIS chimera and assays performed in the absence or presence of the inhibitor in cell sonicates. Entirely analogous results were obtained with the hZ44085/DIII SECIS chimera. 


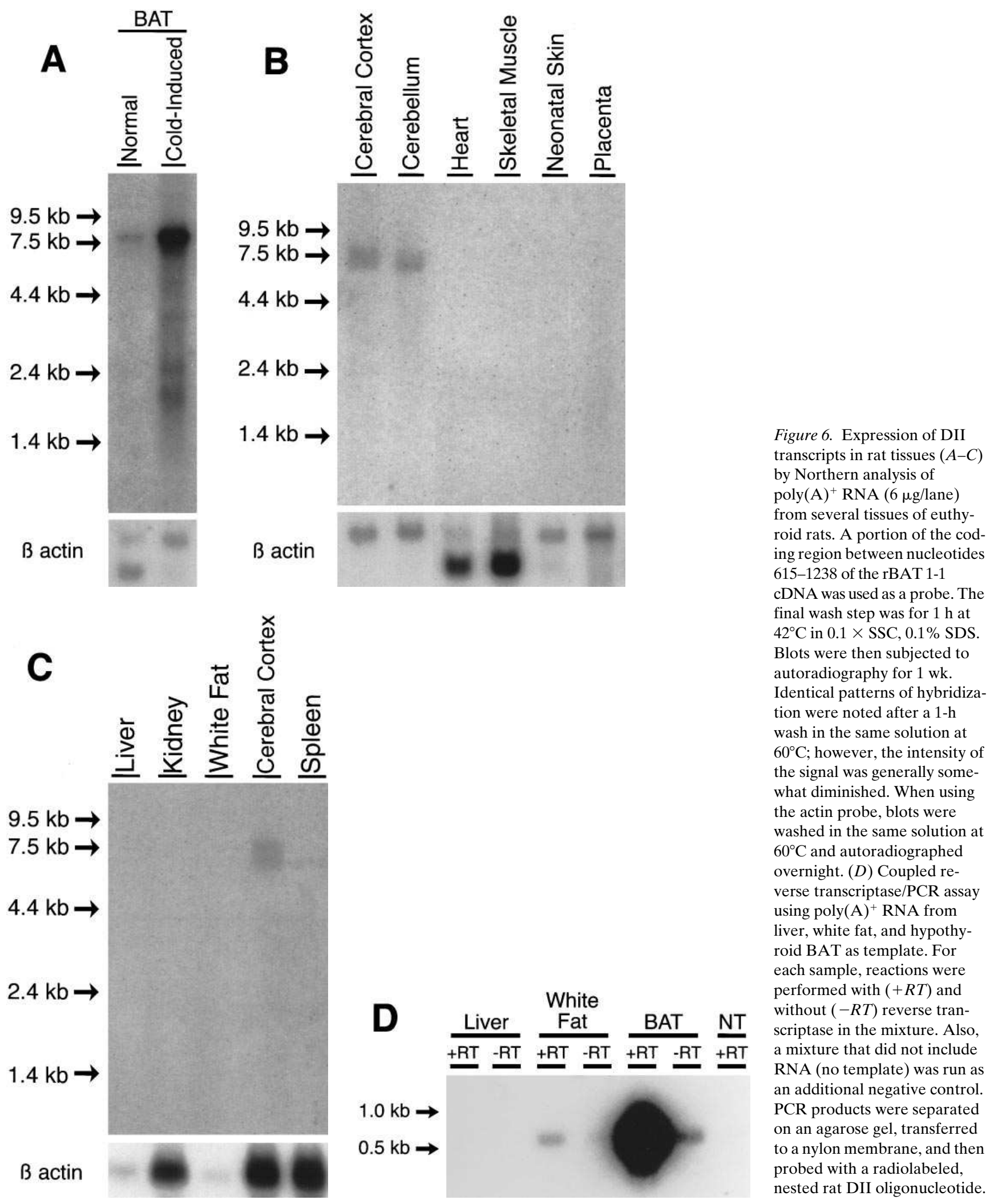

has been demonstrated for other deiodinase cDNAs $(7,9)$. Thus, chimeric constructs were prepared by replacing part or all of the 3'-untranslated regions of the rBAT 1-1 and hZ44085 cDNAs, respectively, with the $3^{\prime}$-untranslated region of the
rNS43-1 that contains a potent SECIS element (Moyer, B., and D.L. St. Germain, unpublished observations). In both chimeric constructs, the coding regions of the rBAT 1-1 and hZ44085 cDNAs remained intact. 


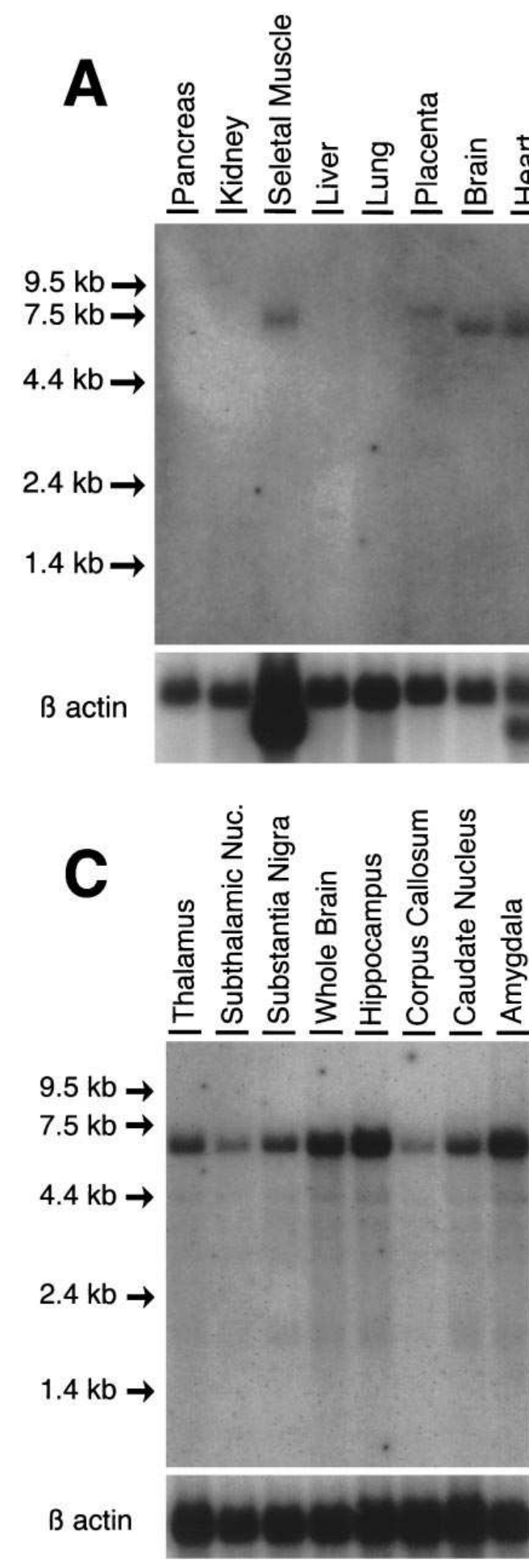

As shown in Fig. 3, the injection into oocytes of RNA transcripts derived from the $\mathrm{rBAT} 1-1 / \mathrm{rDIII}$ SECIS chimera cDNA induced $5^{\prime}$-, but not 5-deiodinase activity. In the same experiment, the G21 and the rNS43-1 cDNAs induced high levels of 5' - or 5-deiodinase activity, respectively.

When examined in rat tissue homogenates, the DII exhibits several characteristic properties including: $(a) \mathrm{K}_{\mathrm{m}}$ values in the nanomolar range for iodothyronine substrates; $(b)$ the ability to efficiently $5^{\prime}$-deiodinate $\mathrm{T}_{4}$ as well as $\mathrm{rT}_{3}$; and $(c)$ rel-
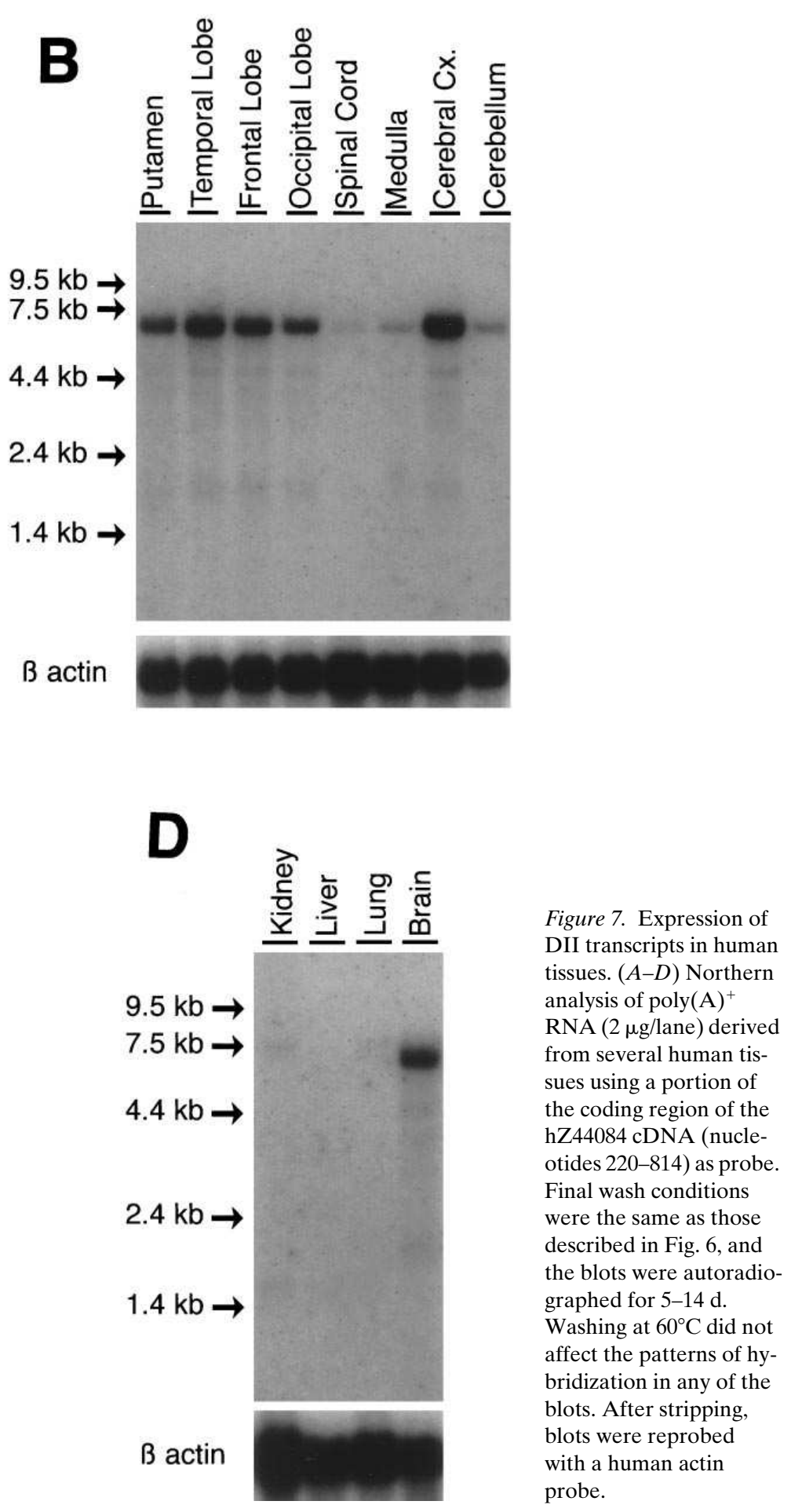

ative insensitivity to the inhibitory effects of PTU and gold compounds such as aurothioglucose (29). Using the oocyte and COS-7 cell expression systems, the functional properties of the proteins coded by the rat and human chimeric cDNA constructs were investigated. Kinetic analyses performed in sonicates of transfected COS-7 cells are shown in Fig. 4. Both enzymes showed saturable reaction kinetics with $K_{m}$ values for $\mathrm{T}_{4}$ and $\mathrm{rT}_{3}$ of $\sim 1$ and $5 \mathrm{nM}$, respectively. $\mathrm{V}_{\max }$ values using $\mathrm{rT}_{3}$ as substrate were 75 and $33 \%$ higher for the rat and hu- 

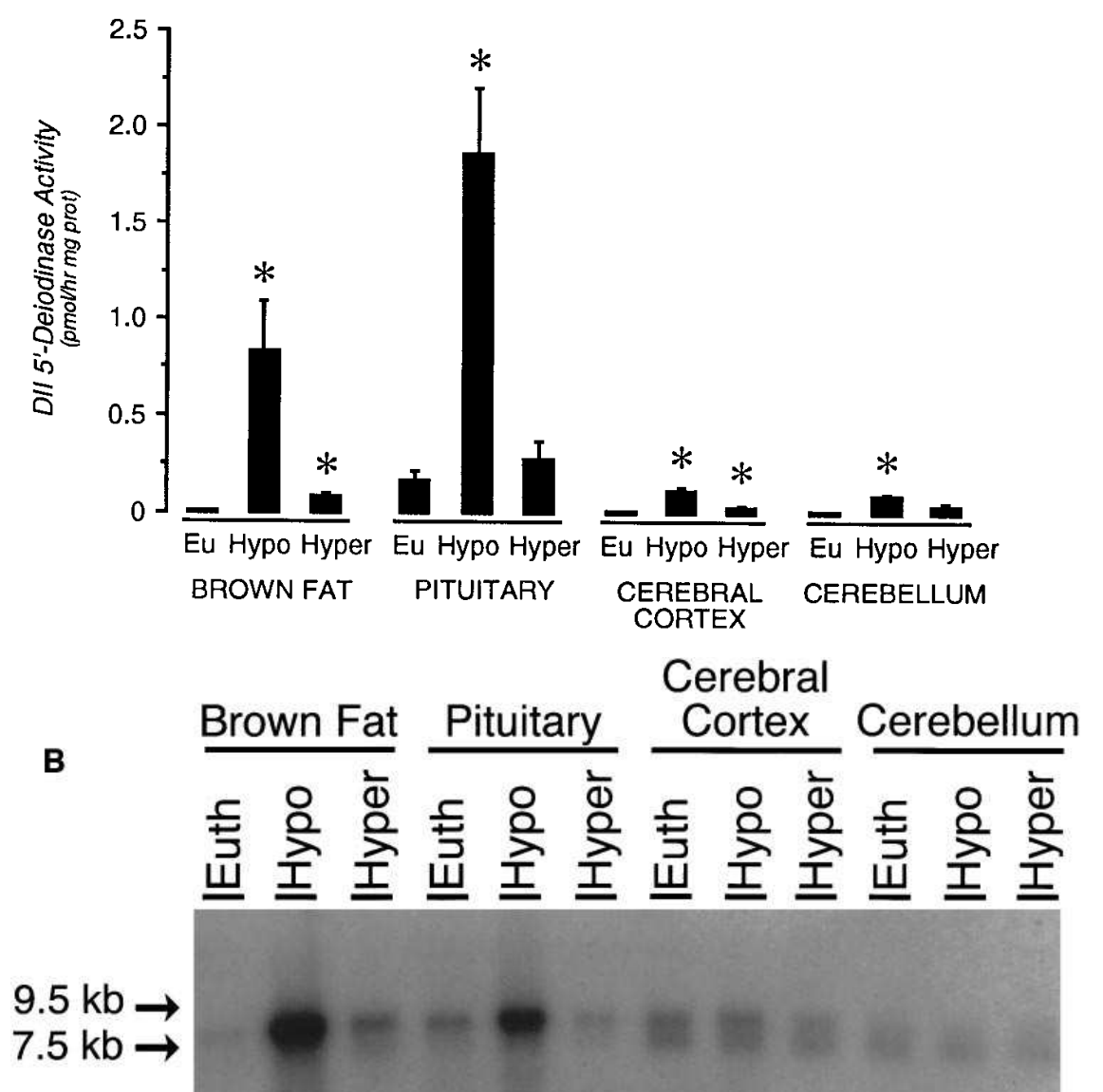

$4.4 \mathrm{~kb} \rightarrow$

$2.4 \mathrm{~kb} \rightarrow$

$1.4 \mathrm{~kb} \rightarrow$

B actin

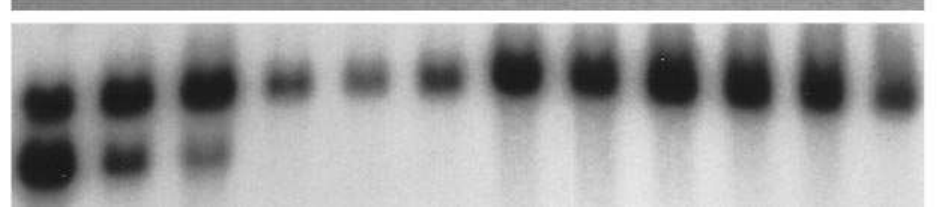

Figure 8. Effect of altered thyroid hormone status on DII $(A)$ activity and $(B)$ mRNA levels in the BAT, anterior pituitary gland, cerebral cortex, and cerebellum of rats. Rats were rendered hypo- and hyperthyroid as described in Methods. For determination of DII activity, individual tissues were harvested from three rats, homogenized, and assayed in the presence of $0.1 \mathrm{mM}$ PTU using $1.5 \mathrm{nM} \mathrm{rT}_{3}$ as substrate and $20 \mathrm{mM}$ dithiothreitol as cofactor. Results represent the mean \pm SEM. $* P<0.05$ vs euthyroid value. For Northern blot analysis, RNA was prepared from BAT and cerebral cortex of individual animals, from a pool of three cerebellums, and from a pool of 10 anterior pituitary glands. Approximately $10 \mu \mathrm{g}$ (brown fat, cerebral cortex, and cerebellum) or $5 \mu \mathrm{g}$ (pituitary) of poly(A) ${ }^{+}$RNA were loaded per lane on the gel. man enzymes, respectively, when compared to values obtained with $\mathrm{T}_{4}$.

The rBAT 1-1 deiodinase proved to be insensitive to inhibition by PTU and aurothioglucose. PTU, $100 \mu \mathrm{M}$, had no effect on 5'-deiodinase activity, whereas DI activity induced by the expression of the G21 cDNA was inhibited by 90\% (Fig. $5 \mathrm{~A}$ ). The hZ44085 protein also proved completely insensitive to PTU at concentrations as high as $900 \mu \mathrm{M}$ (data not shown). Although aurothioglucose did inhibit both the rBAT 1-1 and hZ44085 enzyme activity, a much higher concentration ( $>10$-fold) was required to achieve inhibition comparable to that observed with the DI (Fig. $5 B$, and data not shown for the hZ44085 enzyme).

The expression of rBAT 1-1-associated mRNA was investigated in rat tissues by Northern analysis and coupled reverse transcription PCR. A relatively weak hybridization band of 7.5 $\mathrm{kb}$ was noted in RNA from normal BAT (Fig. $6 A$ ). The abundance of this species was increased 17-fold in the sample of RNA from BAT of cold-exposed animals. (In a second experiment, a ninefold increase was noted, data not shown.) In addition, smaller and much less abundant species of $\sim 4.0,2.5$, and $2.0 \mathrm{~kb}$ were also noted in this and other RNA samples from 
this tissue. No hybridization signal was seen with RNA samples from rat heart, white fat, placenta, liver, kidney, neonatal skin, or skeletal muscle (Fig. 6, $B$ and $C$ ). In adult rat cerebral cortex, two major hybridizing species of approximately equal abundance at $7-8 \mathrm{~kb}$ were observed (Figs. $6 B$ and $8 B$, and below). A similar pattern was seen in the cerebellum, though the smaller species of the doublet appears somewhat more abundant in this tissue.

Although no hybridization signal was detected on Northern blots using RNA from rat liver and white fat (Fig. $6 C$ ), the lesser $\beta$-actin control signal in these RNA samples suggested that this analysis was less than definitive. Hence, a coupled reverse transcription-PCR technique was used to examine whether DII transcripts were expressed in these tissues. As shown in Fig. $6 \mathrm{D}$, an abundant PCR product of the expected size (590 bp) was observed when RNA from BAT of a hypothyroid rat was used in the assay (positive control). This signal was markedly diminished in the absence of reverse transcriptase and was absent when the template was excluded from the reaction mixture. A faint signal, only 1/100th the intensity of that observed in BAT, was noted in white fat, whereas no signal was observed in this experiment when liver RNA was used as the template. In another experiment using a higher cycle number, a faint band was detected in liver (data not shown). Such a finding is likely of little physiologic significance and may correspond to the phenomenon of "illegitimate transcription" as defined by Chelly et al. (30).

The hZ44085 cDNA was used to probe RNA blots of human tissues. High levels of expression of a $6.6-\mathrm{kb}$ transcript were noted in brain, skeletal muscle, and heart, with lesser amounts of a larger $7.5-\mathrm{kb}$ species present in placenta and heart (Fig. 7 A). No signal was detectable in pancreas, kidney, liver, or lung. The distribution of hZ44085-associated transcripts in human brain was investigated further (Fig. 7, $B$ and $C$ ). Again the predominant species observed was $\sim 6.6 \mathrm{~kb}$ with transcripts of 4.4, 4.0,3.2, and $1.9 \mathrm{~kb}$ also observed in some tissues. Transcripts appeared abundant throughout the neocortex as well as the putamen, amygdala, and hippocampus. Lesser degrees of expression were noted in the cerebellum, caudate nucleus, substantia nigra, thalamus, subthalamic nucleus, corpus callosum, medulla, and spinal cord.

Because of the known importance of thyroid hormones for brain development, an RNA blot of human fetal tissues (18-24 wk gestation according to the blot manufacturer, Clontech) was also probed with hZ44085 (Fig. 7 D). High levels of expression of a $6.6-\mathrm{kb}$ species were detected in fetal brain, but not in fetal lung, liver, or kidney.

Previous studies have demonstrated that the regulation of DII activity is complex and appears to involve both pre- and posttranslational mechanisms in different tissues $(29,31)$. In particular, thyroid hormones exert important regulatory effects on DII activity as well as on the other deiodinases. Thus, an investigation of the effects of altered thyroid hormone status on the BAT 1-1-associated transcripts was of interest. For this study, DII activity was determined and RNA extracted from several tissues of normal (euthyroid), hypothyroid, and hyperthyroid adult rats. DII activity levels are shown in Fig. 8 $A$. As compared to the euthyroid state, hypothyroidism was associated with a significant increase in activity of 6-, 9-, 11-, and 118-fold in the cerebellum, cerebral cortex, anterior pituitary, and BAT, respectively. In addition, hyperthyroidism induced by $\mathrm{T}_{3}$ administration was associated with a trend toward higher DII activity in all tissues, and this was statistically significant in BAT (11-fold increase in activity) and cerebral cortex (2-fold increase).

The Northern analysis of RNA samples from these rats is shown in Fig. 8 B. Comparison of the hybridization signals in the various tissues from the euthyroid animals demonstrates that rBAT 1-1-associated transcripts are most abundant in the anterior pituitary gland. Thus, the DII transcript levels in the cerebellum, cerebral cortex, and pituitary, when normalized for the actin mRNA signal in each tissue, are $\sim 7-, 30$-, and 50-fold higher, respectively, than those observed in euthyroid BAT. In pituitary and BAT RNA samples, hypothyroidism was associated with a marked increase (3.3- and 12-fold, respectively) in DII transcripts when compared to the levels in euthyroid samples. Furthermore, hyperthyroidism resulted in a $70 \%$ decrease in pituitary DII mRNA relative to the control samples. In contrast, altered thyroid status had little or no effect on the DII transcript levels in the cerebral cortex and cerebellum, where again two species between 7 and $8 \mathrm{~kb}$ were observed.

\section{Discussion}

The present studies demonstrate that the rBAT 1-1 and human hZ44085 code for mammalian DIIs. This conclusion is based on both the functional activity of the expressed proteins and the tissue patterns of expression of their associated mRNAs.

Both the rBAT 1-1 and hZ44085 cDNAs appear to lack functional SECIS elements in their $3^{\prime}$-untranslated regions. (Although it is theoretically possible that the SECIS element could be located in a missing portion of the $5^{\prime}$-untranslated region of these cDNAs, stem loop structures function very inefficiently as SECIS elements in this location, reference 32, and no native 5'-untranslated region SECIS elements have been described.) This explains the inability of these cDNAs to code for proteins with functional deiodinase activities; without an active SECIS element, translation likely terminates at the first TGA triplet located midway through the coding regions of these genes. However, by fashioning chimeric cDNAs in which the open reading frames of the rBAT 1-1 or the hZ44085 were fused to the SECIS-containing 3'-untranslated region of the rNS43-1 rat DIII cDNA, expression of functional deiodinases was obtained.

The properties of these expressed enzymes are entirely consistent with those of the endogenous DII previously defined in mammalian tissue homogenates (33). Thus, both enzymes manifest $\mathrm{K}_{\mathrm{m}}$ values for $\mathrm{T}_{4}$ and $\mathrm{rT}_{3}$ in the low nanomolar range when using $20 \mathrm{mM}$ dithiothreitol as cofactor. Furthermore, using the $\mathrm{V}_{\max } / \mathrm{K}_{\mathrm{m}}$ ratio as an approximate indicator of catalytic efficiency, $\mathrm{T}_{4}$ is the preferred substrate for both enzymes; values of this calculated parameter for $T_{4}$ are three- to fourfold higher than for $\mathrm{rT}_{3}$. This finding contrasts sharply with the catalytic properties of the DI where $\mathrm{rT}_{3}$ is the much preferred substrate, and $T_{4}$ is converted to $T_{3}$ with relatively poor efficiency (33). Also contrasting with the DI is the marked insensitivity of these expressed deiodinases to the inhibitory effects of PTU and gold compounds.

Several studies have provided indirect evidence that the mammalian DII is not a selenoprotein. Such evidence includes (a) the observation that DII activity in rat astrocytes is not diminished when the cells are cultured in selenium deficient medium (34); (b) the inability to label candidate DII proteins with $\left[{ }^{75} \mathrm{Se}\right](34)$; and $(c)$ the insensitivity of the DII to PTU and gold 
A

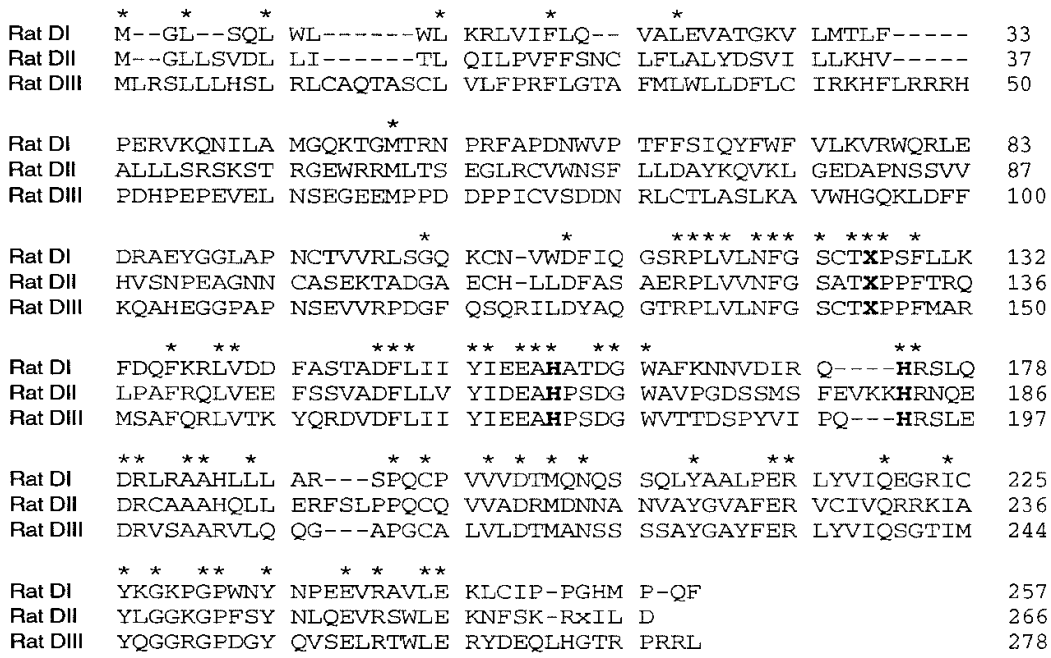

\section{B}

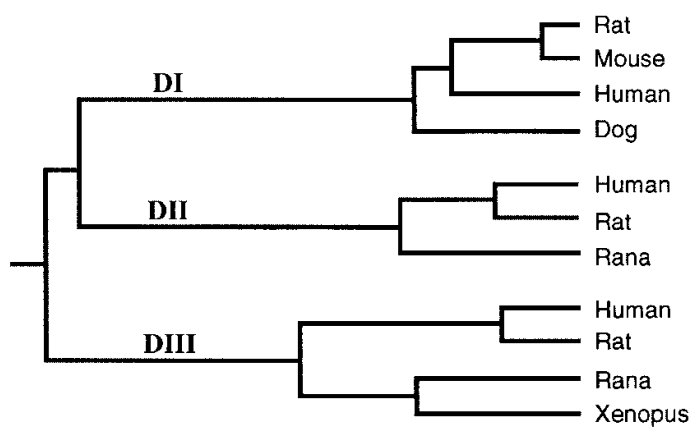

Figure 9. (A) A comparison of the amino acid sequence of the rat DI, DII, and DIII proteins as deduced from the cDNA nucleotide sequence. Asterisks represent amino acid residues that have been conserved identically between these three proteins. X, selenocysteine; $\mathrm{x}$, position of second TGA codon in rat DII. (B) Evolutionary tree diagram based on the deduced amino acid sequences of 11 deiodinase cDNAs reported to date $(7-10,18,71-75)$. inhibitors as noted above (35). Furthermore, although DII activity is modestly diminished in the brain and anterior pituitary gland of selenium-deprived rats (36-38), Chanoine et al. (38) have provided convincing evidence that this results from an increased rate of posttranslational inactivation of the enzyme secondary to elevations in serum, and presumably tissue, $\mathrm{T}_{4}$ levels rather than a selenium-induced decrease in enzyme synthesis.

The present study, however, demonstrates that the rat and human DIIs are selenoproteins that contain a selenocysteine within a region that is highly conserved with the other deiodinases (Fig. $9 A$ ). This observation, along with prior sitedirected mutagenesis studies $(7,9,10,18)$, demonstrates that this rare amino acid is essential for efficient catalysis of iodothyronines by all members of this enzyme family. The inability of Safran et al. (34) to affect DII activity in cultured rat astroglial cells by the manipulation of selenium concentrations in the medium may be related to the findings of others that the brain and pituitary gland, like the thyroid gland and other endocrine organs, are resistant to selenium depletion (39). That this property is maintained in vitro in primary cell culture was recently demonstrated by Beech et al. (40), who were unable to affect the activity of the DI in cultured human thyroid cells by selenium starvation. Furthermore, in whole animal studies, they observed that thyroidal DI activity was actually increased by $42 \%$ in rats on a selenium-deficient diet in spite of a modest
$(30 \%)$ decrease in thyroidal glutathione peroxidase activity, another selenoenzyme. Such results confirm the findings of others (41) indicating that there is a hierarchy of expression of different selenoproteins in a cell in the face of selenium deprivation.

Alternatively, the DII in cultured rat glial cells could lack selenocysteine and be coded by a mRNA that is unrelated to the rBAT 1-1. However, our observations that rBAT 1-1- and hZ44085-associated transcripts are highly expressed in the rat anterior pituitary gland and in the central nervous system of fetal and adult rats and humans strongly suggest that brain DII is coded by these genes. Furthermore, the predicted size of the rBAT 1-1 protein $(29.8 \mathrm{kD})$ is virtually identical to a $29-\mathrm{kD}$ protein identified by affinity labeling techniques in cultured glial cells and proposed by Safran and Leonard to be the DII (42).

In addition to the highly conserved regions surrounding the selenocysteine residue, other shared structural features of the deiodinases are apparent (Fig. $9 A$ ). All three subclasses of deiodinase contain regions of strong hydrophobicity near their amino termini and this may represent membrane-spanning domains (28). Furthermore, two histidine residues demonstrated by Berry (43) to be essential for catalysis by the DI (residues 158 and 174 in the rat DI) are conserved in the DII and the DIII enzymes. The second in-frame TGA triplet is unique to the rat and human DII cDNAs. Whether these code for a second selenocysteine in these proteins or function in their more 
traditional role as stop codons is uncertain. It appears likely, however, that a second selenocysteine is not required for DII activity since this second TGA codon is not present in the RC5'DII cDNA (Fig. 2 B). A comparison of the amino acid sequence of the 11 deiodinases for which cDNAs have been isolated to date is shown as an evolutionary tree diagram in Fig. $9 \mathrm{~B}$. This analysis demonstrates that the DIs, DIIs, and DIIIs form three separate subfamilies, each approximately equally dissimilar to the other two. Furthermore, based on these limited data, the members within the DII subfamily appear more highly conserved across species lines than the DI or DIII.

The tissue expression of rBAT 1-1-associated transcripts is consistent with the known distribution of DII activity in the rat (33); hybridizing RNA species were observed in the anterior pituitary gland, cerebral cortex, cerebellum, and BAT. In BAT, where cold exposure induces DII activity (26), a 9-17-fold increase in abundance of a $7.5-\mathrm{kb}$ band was noted in response to this stimulus. The large size of the predominant DII transcript observed in both the rat and human was unexpected given the much smaller size ( $\sim 1.6-2.2 \mathrm{~kb}$ ) of the DI (44) and DIII mRNAs $(9,10)$, and our prior observation that in Rana catesbeiana the predominant DII mRNA is $1.5 \mathrm{~kb}$ (18). Thus, the rBAT 1-1 and hZ44085 cDNAs, both $\sim 1.9 \mathrm{~kb}$, are not full length with respect to the 6-8-kb DII mRNAs. This likely explains the lack of SECIS elements in their presumably truncated 3 '-untranslated regions. Both cDNAs, however, do contain the entire coding region for the DII proteins. The finding that the rBAT 1-1 cDNA contains a long poly $(\mathrm{A})^{+}$tail at its $3^{\prime}$ end suggests that it is derived from one of the smaller, less abundant RNA species observed on Northern blots of RNA from BAT of cold-exposed animals. Thus, either alternative RNA splicing or the use of alternative polyadenylation sites may be a feature of the processing of the mammalian DII mRNA.

Information on the distribution of the deiodinases in humans is limited $(8,45,46)$. The present studies demonstrate that DII transcripts are more widely distributed in this species than in the rat. Thus, in addition to its expression in the central nervous systems, DII mRNA was also observed in the human placenta, heart, and skeletal muscle at levels comparable to those observed in the brain. In contrast, no hybridizing species could be detected with RNA from these nonneural tissues in rats, consistent with earlier reports that rat heart $(47,48)$ and skeletal muscle (49) contain only low levels of DI activity and no detectable DII activity. Rat placenta, however, does contain DII activity (46). Thus, our failure to detect DII mRNA by Northern analysis in rat placenta likely results from the relatively low abundance of this transcript.

The pattern of DII expression in the human fetus (Fig. $7 \mathrm{D}$ ) is of considerable interest given the prior report by Bernal and Pekonen (50) that $\mathrm{T}_{3}$ and nuclear $\mathrm{T}_{3}$ receptors are detectable in human fetal brain as early as $10 \mathrm{wk}$ of gestation, long before $\mathrm{T}_{3}$ becomes detectable in the serum (51). Thus, DII expression in the central nervous system early in gestation is likely of great importance for the generation of the T3 needed by this tissue. Of note, tissues such as the liver and lung, which do not express DII at this early stage of development, do not contain detectable $\mathrm{T}_{3}(50)$, thus reinforcing the importance of this enzyme in regulating local $\mathrm{T}_{3}$ tissue concentrations.

Northern analyses revealed that the expression of DII transcripts in the human adult brain is widespread and shows a general rostral-caudal distribution. This regional pattern of
DII expression correlates closely with the relative abundance of thyroid hormone nuclear receptors in various regions of the adult rat central nervous system as defined by both saturation analysis (52) and $\mathrm{T}_{3}$ receptor mRNA expression (53). Although the importance of thyroid hormone in the developing brain is unquestioned $(54,55)$, there continues to be controversy concerning the role of these hormones in adult brain function (56). Thus, the apparent coexpression of the DII and thyroid hormone receptors in several regions of the adult human brain provides strong evidence for a continuing important role of $\mathrm{T}_{3}$ after the developmental period and reinforces clinical observations of altered central nervous system function in states of hypo- and hyperthyroidism (56-58). Of particular note are the relatively high levels of expression of DII transcripts in the hippocampus, amygdala, and basal ganglion, suggesting an important influence of thyroid hormones on memory and learned patterns of movement (59). Such effects might explain some of the cognitive dysfunction seen in adults with altered thyroid function as well as the movement disorders observed in neurologic cretinism (60).

To our knowledge, adult human heart and skeletal muscle have not been examined for the presence of DII activity. However, the expression of DII in these tissues, as suggested by the results of the Northern analysis, could be of considerable physiologic importance. For example, LoPresti et al. (61) have demonstrated that the serum $\mathrm{T}_{3}$ level in euthyroid subjects is unaltered after $4 \mathrm{~d}$ by the administration of high doses of PTU, suggesting an important role for the DII in maintaining circulating $\mathrm{T}_{3}$ concentrations in healthy humans. DII expression in skeletal muscle could provide a source for such $\mathrm{T}_{3}$ production. In addition, several investigators have demonstrated that in rats, DII-containing tissues (predominantly the cerebral cortex and BAT) are able to maintain relatively normal tissue $\mathrm{T}_{3}$ levels, and hence presumably a euthyroid state, over a wide range of plasma $\mathrm{T}_{4}$ levels (62-64). Thus, human heart and skeletal muscle may also be relatively protected from the effects of hypothyroidism.

DII activity in rat tissues is markedly influenced by thyroid hormone status. For example, hypothyroidism is associated with marked elevations in DII activity $(65,66)$. In the central nervous system and anterior pituitary gland, posttranslational processes are important in mediating this effect $(67,68)$, whereas in BAT, multiple pre- and posttranslational mechanisms appear to influence DII activity in hypo- and hyperthyroid states $(27,31)$. The cloning of the rBAT 1-1 cDNA allowed us to investigate further these complex processes by focusing specifically on pretranslational mechanisms of regulation (Fig. 8). As expected from previous studies, the induction of hypothyroidism resulted in a marked increase in DII activity in all tissues studied. This was associated with a significant increase in DII mRNA expression in BAT and the pituitary, but little if any change in the cerebral cortex and cerebellum. It is thus apparent that in the brain, thyroid hormone regulates DII activity predominantly, if not exclusively, via posttranslational mechanisms as previously described (67). In BAT, Silva and Larsen (31) have demonstrated that the growth hormone deficiency that accompanies hypothyroidism stimulates DII activity, an effect that is blocked by actinomycin. Thus, the alterations in DII transcript levels in this tissue are likely due at least in part to a secondary effect of the thyroid hormone deficiency.

The significant increase in DII transcripts in the pituitary of hypothyroid animals demonstrates that pretranslational fac- 
tors, in addition to the previously cited posttranslational effects of thyroid hormones, are responsible in part for the marked rise in DII activity in this tissue. Whether this increase represents a direct effect of thyroid hormone on DII mRNA levels is uncertain, but it seems plausible given that, unlike BAT, catecholamines and growth hormone have no demonstrable effect on pituitary DII activity $(26,31)$. A direct effect is also consistent with a recent study by Halperin et al. (69) who noted that $\mathrm{T}_{3}$ was more potent than $\mathrm{rT}_{3}$ in downregulating DII activity in cultured rat pituitary GC cells, an effect that they suggest is mediated by the nuclear thyroid hormone receptor. Alternatively, the increase in DII transcripts in hypothyroidism could be secondary to a relative increase in abundance of a pituitary cell type that expresses comparatively high DII levels. Indeed, the fraction of thyrotrophs has been observed to increase from $10.7 \%$ in the euthyroid rat pituitary gland to $34.4 \%$ in chronic hypothyroidism (70). Thyrotrophs, however, appear to contain less DII activity than other pituitary cell types (71). Thus an increase in the proportion of thyrotrophs is an unlikely explanation for our findings.

In our experiment, hyperthyroidism, as induced by $4 \mathrm{~d}$ of $\mathrm{T}_{3}$ injections, was also associated with an increase in DII activity, though to a considerably lesser extent than that seen with hypothyroidism. Although not proven, this likely results primarily from thyroid-stimulating hormone suppression, leading to reduced serum and tissue $\mathrm{T}_{4}$ levels, and hence decreased posttranslational inactivation of the DII protein (67). Such a phenomenon has been noted previously in BAT (31), but has not been investigated in other tissues expressing DII.

In summary, we have identified cDNAs for the rat and human DII and have demonstrated that they code for selenoproteins that manifest critical areas of homology with the other deiodinase subtypes. The expression of the DII in mammalian brain, pituitary, BAT, heart, skeletal muscle, and placenta highlights the importance of thyroid hormone in regulating metabolic activity in these tissues, and lends further support to the concept that the DII is a critical modulator of thyroid hormone action.

\section{Acknowledgments}

The authors thank Pascal Soularve (Genethon) for generously providing the Z44085 cDNA.

This study was supported by the National Institutes of Health grants DK-42271 (D.L. St. Germain), HD-27706 (V.A. Galton), and HD-09020 (V.A. Galton) and the Norris Cotton Cancer Center Core grant CA 23108.

\section{References}

1. Crantz, F.R., J.E. Silva, and P.R. Larsen. 1982. An analysis of the sources and quantity of 3,5,3'-triiodothyronine specifically bound to nuclear receptors in rat cerebral cortex and cerebellum. Endocrinology. 110:367-375.

2. Silva, J.E., and P. Matthews. 1984. Thyroid hormone metabolism and the source of plasma triiodothyronine in 2-week-old rats: effects of thyroid status. Endocrinology. 115:2394-2405.

3. Bianco, A.C., and J.E. Silva. 1987. Nuclear 3,5,3' -triiodothyronine (T3) in brown adipose tissue: receptor occupancy and sources of $\mathrm{T} 3$ as determined by in vivo techniques. Endocrinology. 120:55-62.

4. van Doorn, J., F. Roelfsema, and D. van der Heide. 1985. Concentration of thyroxine and 3,5,3'-triiodothyronine at 34 different sites in euthyroid rats as determined by isotopic equilibrium techniques. Endocrinology. 117:1201-1208.

5. Silva, J.E., and P.R. Larsen. 1986. Regulation of thyroid hormone expression at the prereceptor and receptor levels. In Thyroid Hormone Metabolism. G. Hennemann, editor. Marcel Dekker, Inc., New York. 441-500.

6. Silva, J.E., M.B. Gordon, F.R. Crantz, J.L. Leonard, and P.L. Larsen.
1984. Qualitative and quantitative differences in the pathways of extrathyroidal triiodothyronine generation between euthyroid and hypothyroid rats. J. Clin. Invest. 73:898-907.

7. Berry, M.J., L. Banu, and P.R. Larsen. 1991. Type I iodothyronine deiodinase is a selenocysteine-containing enzyme. Nature (Lond.). 349:438-440.

8. Mandel, S.J., M.J. Berry, J.D. Kieffer, J.W. Harney, R.L. Warne, and P.R. Larsen. 1992. Cloning and in vitro expression of the human selenoprotein, type I iodothyronine deiodinase. J. Clin. Endocrinol. \& Metab. 75:1133-1139.

9. St. Germain, D.L., R. Schwartzman, W. Croteau, A. Kanamori, Z. Wang, D.D. Brown, and V.A. Galton. 1994. A thyroid hormone regulated gene in Xenopus laevis encodes a type III iodothyronine 5-deiodinase. Proc. Natl. Acad. Sci. USA. 91:7767-7771. Correction. Proc. Natl. Acad. Sci. USA. 91:11282.

10. Croteau, W., S.L. Whittemore, M.J. Schneider, and D.L. St. Germain. 1995. Cloning and expression of a cDNA for a mammalian type III iodothyronine deiodinase. J. Biol. Chem. 270:16569-16575.

11. Beech, S.G., S.W. Walker, A.M. Dorrance, J.R. Arthur, J.R. Nicol, D. Lee, and G.J. Beckett. 1993. The role of type-I iodothyronine deiodinase in triiodothyronine production by human and sheep thyrocytes in culture. J. Endocrinol. 136:361-370.

12. Chanoine, J., L.E. Braverman, A.P. Farwell, M. Safran, S. Alex, S. Dubord, and J.L. Leonard. 1993. The thyroid gland is a major source of circulating T3 in the rat. J. Clin. Invest. 91:2709-2713.

13. Moreno, M., M.J. Berry, C. Horst, R. Thoma, F. Goglia, J.W. Harney, P.R. Larsen, and T.J. Visser. 1994. Activation and inactivation of thyroid hormone by type I iodothyronine deiodinase. FEBS Lett. 344:143-146.

14. St. Germain, D.L. 1994. Biochemical study of type III iodothyronine deiodinase. In Thyroid Hormone Metabolism: Molecular Biology and Alternative Pathways. S.-Y. Wu, and T. J. Visser, editors. CRC Press, Ann Arbor, MI. 45-66.

15. McCann, U.D., E.A. Shaw, and M.M. Kaplan. 1984. Iodothyronine deiodination reaction types in several rat tissues: effects of age, thyroid status, and glucocorticoid treatment. Endocrinology. 114:1513-1521.

16. Calvo, R., M.J. Obregón, C. Ruiz de Ona, F. Escobar del Rey, and G.M. de Escobar. 1990. Congenital hypothyroidism, as studied in rats: crucial role of maternal thyroxine but not $3,5,3^{\prime}$-triiodothyronine in the protection of the fetal brain. J. Clin. Invest. 86:889-899.

17. St. Germain, D.L., and W. Croteau. 1989. Expression of phenolic and tyrosyl ring iodothyronine deiodinases in Xenopus laevis oocytes is dependent on the tissue source of injected poly(A)+ RNA. Mol. Endocrinol. 3:2049-2053.

18. Davey, J.C., K.B. Becker, M.J. Schneider, D.L. St. Germain, and V.A. Galton. 1995. Cloning of a cDNA for the type II iodothyronine deiodinase. J. Biol. Chem. 270:26786-26789.

19. St. Germain, D.L., and C.M. Morganelli. 1989. Expression of type I iodothyronine $5^{\prime}$-deiodinase in Xenopus laevis oocytes. J. Biol. Chem. 264:30543056 .

20. DePalo, D., W.B. Kinlaw, C. Zhao, H. Engelberg-Kulka, and D.L. St. Germain. 1994. Effect of selenium deficiency on type I 5'-deiodinase. J. Biol. Chem. 269:16223-16228.

21. Lees, J.A., M. Saito, M. Vidal, M. Valentine, T. Look, E. Harlow, N. Dyson, and K. Helin. 1993. The retinoblastoma protein binds to a family of E2F transcription factors. Mol. Cell. Biol. 13:7813-7825.

22. Sharifi, J., and D.L. St. Germain. 1992. The cDNA for the type I iodothyronine $5^{\prime}$-deiodinase encodes an enzyme manifesting both high $\mathrm{K}_{\mathrm{m}}$ and low $\mathrm{K}_{\mathrm{m}}$ activity. J. Biol. Chem. 267:12539-12544.

23. Bradford, M.M. 1976. A rapid and sensitive method for quantitation of microgram quantities of protein utilizing the principle of protein-dye binding. Anal. Biochem. 72:248-254.

24. Horton, R.M., S.N. Ho, J.K. Pullen, H.D. Hunt, Z. Cai, and L.R. Pease. 1993. Gene splicing by overlap extension. Methods Enzymol. 217:270-278.

25. Godfrey, K. 1985. Comparing the means of several groups. N. Engl. J. Med. 13:1450-1456.

26. Silva, J.E., and P.R. Larsen. 1983. Adrenergic activation of triiodothyronine production in brown adipose tissue. Nature (Lond.). 305:712-713.

27. Silva, J.E., and P.R. Larsen. 1986. Hormonal regulation of iodothyronine 5'-deiodinase in rat brown adipose tissue. Am. J. Physiol. 251:639-643.

28. Toyoda, N., M.J. Berry, J.W. Harney, and P.R. Larsen. 1995. Topological analysis of the integral membrane protein, type 1 iodothyronine deiodinase (D1). J. Biol. Chem. 270:12310-12318.

29. St. Germain, D.L. 1994. Iodothyronine deiodinases. Trends Endocrinol. Metab. 5:36-42.

30. Chelly, J., J.-P. Concordet, J.-C. Kaplan, and A. Kahn. 1989. Illegitimate transcription: transcription of any gene in any cell type. Proc. Natl. Acad. Sci. USA. 86:2617-2621.

31. Silva, J.E., and P.R. Larsen. 1986. Interrelationships among thyroxine, growth hormone, and the sympathetic nervous system in the regulation of $5^{\prime}$-iodothyronine deiodinase in rat brown adipose tissue. J. Clin. Invest. 77:1214-1223.

32. Berry, M.J., L. Banu, J.W. Harney, and P.R. Larsen. 1993. Functional characterization of the eukaryotic SECIS elements which direct selenocysteine insertion at UGA codons. EMBO (Eur. Mol. Biol. Organ.) J. 12:3315-3322.

33. Leonard, J.L. 1991. Biochemical basis of thyroid hormone deiodination. In Thyroid Hormone Metabolism: Regulation and Clinical Implications. S. Wu, editor. Blackwell Scientific Publications, Boston, MA. 1-28. 
34. Safran, M., A.P. Farwell, and J.L. Leonard. 1991. Evidence that type II 5'-deiodinase is not a selenoprotein. J. Biol. Chem. 266:13477-13480.

35. Berry, M.J., J.D. Kieffer, and P.R. Larsen. 1991. Evidence that cysteine, not selenocysteine is in the catalytic site of type II iodothyronine deiodinase. Endocrinology. 129:550-552.

36. Beckett, G.J., D.A. MacDougal, F. Nicol, and J.R. Arthur. 1989. Inhibition of types I and II iodothyronine deiodinase activity in rat liver, kidney and brain produced by selenium deficiency. Biochem. J. 259:887-892.

37. Meinhold, H., A. Campos-Barros, B. Walzog, R. Köhler, F. Müller, and D. Behne. 1993. Effects of selenium and iodine deficiency on type I, type II, and type III iodothyronine deiodinases and circulating thyroid hormones in the rat. Exp. Clin. Endocrinol. 101:87-93.

38. Chanoine, J.P., M. Safran, A.P. Farwell, P. Tranter, D.M. Ekenbarger, S. Dubord, S. Alex, J.R. Arthur, G.J. Becker, L.E. Braverman, and J.L. Leonard. 1992. Selenium deficiency and type II 5'deiodinase regulation in the euthyroid and hypothyroid rat: evidence of a direct effect of thyroxine. Endocrinology. 130:479-484

39. Behne, D., H. Hilmert, S. Scheid, H. Gessner, and W. Elger. 1988. Evidence for specific selenium target tissues and new biologically important selenoproteins. Biochim. Biophys. Acta. 966:12-21.

40. Beech, S.G., S.W. Walker, G.J. Beckett, J.R. Arthur, F. Nicol, and D. Lee. 1995. Effect of selenium depletion on thyroidal type-I iodothyronine deiodinase activity in isolated human thyrocytes and rat thyroid and liver. Analyst. 120:827-831.

41. Gross, M., M. Oertel, and J. Köhrle. 1995. Differential selenium-dependent expression of type I 5'-deiodinase and glutathione peroxidase in the porcine epithelial kidney cell line LLC-PK1. Biochem. J. 306:851-856.

42. Safran, M., and J.L. Leonard. 1991. Comparison of the physiochemical properties of type I and type II iodothyronine 5'-deiodinase. J. Biol. Chem. 266: 3233-3238.

43. Berry, M. 1992. Identification of essential histidine residues in rat type I iodothyronine deiodinase. J. Biol. Chem. 267:18055-18059.

44. St. Germain, D.L., W. Dittrich, C.M. Morganelli, and V. Cryns. 1990. Molecular cloning by hybrid arrest of translation in Xenopus laevis oocytes: identification of a cDNA encoding the type I iodothyronine 5 '-deiodinase from rat liver. J. Biol. Chem. 265:20087-20090.

45. Kaplan, M.M., C.Y. Pan, P.R. Gordon, and B.A. Gilchrest. 1987. Human epidermal keratinocytes convert thyroxine to triiodothyronine by type II deiodination. Clin. Res. 35:388(Abstr.)

46. Kaplan, M.M., and E.A. Shaw. 1984. Type II iodothyronine 5'-deiodination in human and rat placenta in vitro. J. Clin. Endocrinol. \& Metab. 59:253257.

47. Mori, Y , M. Nishikawa, N. Toyoda, T. Yonemoto, H. Matsubara, and M. Inada. 1991. Iodothyronine 5'-deiodinase activity in cultured rat myocardial cells: characteristics and effects of triiodothyronine and angiotensin II. Endocrinology. 128:3105-3112.

48. Nauman, A., J. Nauman, S. Porta, and W. Grzesiuk. 1994. Iodothyronine-5'-deiodinase in rat heart, regulatory action of catecholamines. In Heart and Thyroid. L. E. Braverman, O. Eber, and W. Langsteger, editors. Blackwell Scientific Publications Inc., Cambridge, MA. 169-172.

49. Tsukahara, F., T. Nomoto, and M. Maeda. 1989. Properties of 5'-deiodi-

50. Bernal, J., and F. Pekonen. 1984. Ontogenesis of the nuclear 3,5,3'-triiodothyronine receptor in the human fetal brain. Endocrinology. 114:677-679.

51. Abuid, J., A.H. Klein, T.P.J. Foley, and P.R. Larsen. 1974. Total and free triiodothyronine and thyroxine in early infancy. J. Clin. Endocrin. \& Metabol. 39:263-268.

52. Gullo, D., A.K. Sinha, A. Bashir, M. Hubank, and R.P. Ekins. 1987. Differences in nuclear triiodothyronine binding in rat brain cells suggest phylogenetic specialization of neuronal functions. Endocrinology. 120:2398-2403.

53. Mellström, B., J.R. Naranjo, A. Santos, A.M. Gonzalez, and J. Bernal. 1991. Independent expression of the $\alpha$ and $\beta$ c-erbA genes in developing rat brain. Mol. Endocrinol. 5:1339-1350.

54. Pasquini, J.M., and A.M. Adamo. 1994. Thyroid hormones and the central nervous system. Dev. Neurosci. 16:1-8.

55. Porterfield, S.P., and C.E. Hendrich. 1993. The role of thyroid hormones in prenatal and neonatal neurological development-current perspec- tives. Endocr. Rev. 14:94-106.

56. Sinha, A.K., M.R. Pickard, K.D. Kim, M.T. Ahmed, F. Al Yatama, I.M Evans, and R.P. Ekins. 1994. Perturbations of thyroid hormone homeostasis in the adult and brain function. Acta Med. Austriaca. 21:35-43.

57. Whybrow, P.C. 1991. Behavioral and psychiatric aspects of Hypothy roidism. In The Thyroid: a Fundamental and Clinical Text. L.E. Braverman and R.D. Utiger, editors. J.B. Lippincott Co., New York. 1078-1083.

58. Whybrow, P.C. 1991. Behavioral and psychiatric aspects of thyrotoxicosis. In The Thyroid: a Fundamental and Clinical Text. L.*******E. Braverman and R.D. Utiger, editors. J. B. Lippincott Co., New York. 863-870.

59. Bunsey, M., and H. Eichenbaum. 1996. Conservation of hippocampal memory functions in rats and humans. Nature (Lond.). 379:255-257.

60. DeLong, G.R., and R.D. Adams. 1991. The neuromuscular system and brain in hypothryoidism. In The Thyroid: a Fundamental and Clinical Text L.E. Braverman and R.D. Utiger, editors. J.B. Lippincott Co., New York. 1027-1039.

61. LoPresti, J.S., A. Eigen, E. Kaptein, K.P. Anderson, C.A. Spencer, and J.T. Nicoloff. 1989. Alterations in 3,3',5'-triiodothyronine metabolism in response to propylthiouracil, dexamethasone, and thyroxine administration in man. J. Clin. Invest. 84:1650-1656.

62. Silva, J.E., and P.S. Matthews. 1984. Production rates and turnover of triiodothyronine in rat-developing cerebral cortex and cerebellum: responses to hypothyroidism. J. Clin. Invest. 74:1035-1049.

63. Carvalho, S.D., E.T. Kimura, A.C. Bianco, and J.E. Silva. 1991. Central role of brown adipose tissue thyroxine $5^{\prime}$-deiodinase on thyroid hormonedependent thermogenic response to cold. Endocrinology. 128:2149-2159.

64. Escobar-Morreale, H., M.J. Obregón, F. Escobar del Rey, and G. Morreale de Escobar. 1995. Replacement therapy for hypothyroidism with thyroxine alone does not ensure euthyroidism in all tissues, as studied in thyroidectomized rats. J. Clin. Invest. 96:2828-2838.

65. Leonard, J.L., S.A. Mellen, and P.R. Larsen. 1983. Thyroxine 5' -deiodinase activity in brown adipose tissue. Endocrinology. 112:1153-1155.

66. Silva, J.E., and J.L. Leonard. 1985. Regulation of rat cerebrocortical and adenohypophyseal type II 5'-deiodinase by thyroxine, triiodothyronine, and reverse triiodothyronine. Endocrinology. 116:1627-1635.

67. Leonard, J.L., J.E. Silva, M.M. Kaplan, S.A. Mellen, T.J. Visser, and P.R. Larsen. 1984. Acute posttranscriptional regulation of cerebrocortical and pituitary iodothyronine $5^{\prime}$-deiodinases by thyroid hormone. Endocrinology. 114:998-1004.

68. St. Germain, D.L. 1985. Metabolic effect of 3,3',5'-triiodothyronine in cultured growth hormone producing rat pituitary tumor cells: evidence for a unique mechanism of thyroid hormone action. J. Clin. Invest. 76:890-893.

69. Halperin, Y., L.E. Shapiro, and M.I. Surks. 1994. Down-regulation of type II L-thyroxine, 5'-monodeiodinase in cultured GC cells: different pathways of regulation by L-triiodothyronine and 3,3',5'-triiodo-L-thyronine. Endocrinology. 135:1464-1469.

70. Surks, M.I., and C.R. DeFresi. 1977. Determination of the cell number of each cell type in the anterior pituitary of euthyroid and hypothryoid rats. Endocrinology. 101:946-958.

71. Koenig, R.J., J.L. Leonard, D. Senator, N. Rappaport, A.Y. Watson, and P.R. Larsen. 1984. Regulation of thyroxine $5^{\prime}$-deiodinase activity by $3,5,3^{\prime}-$ triiodothyronine in cultured rat anterior pituitary cells. Endocrinology. 115: 324-329.

72. Maia, A.L., M.J. Berry, R. Sabbag, J. Harney, and P.R. Larsen. 1995. Structural and functional differences in the diol gene in mice with inherited type I deiodinase deficiency. Mol. Endocrinol. 9:969-980.

73. Salvatore, D., S.C. Low, M. Berry, A.L. Maia, J.W. Harney, W. Croteau, D.L. St. Germain, and P.R. Larsen. 1995. Type 3 iodothyronine deiodinase: cloning, in vitro expression, and functional analysis of the placental selenoprotein. J. Clin. Invest. 96:2421-2430.

74. Becker, K.B., M.J. Schneider, J.C. Davey, and V.A. Galton. 1995. The type III 5-deiodinase in Rana catesbeiana tadpoles is encoded by a thyroid hormone-responsive gene. Endocrinology. 136:4424-4431.

75. Toyoda, N., J.W. Harney, M.J. Berry, and P.R. Larsen. 1994. Identification of critical amino acids for 3,5,3'-triiodothyronine deiodination by human type I deiodinase based on comparative functional-structural analysis of the human, dog, and rat enzymes. J. Biol. Chem. 269:20329-20334. 